\title{
Nogeens: Sending en Evangelisasie. Onderlinge verhouding, draagwydte en strukturering ${ }^{1}$
}

J J Kritzinger

\section{ABSTRACT}

Yet again: mission and evangelism. Mutual relationship, range and structuring

In the past the distinction between "mission" and "evangelism" was usually seen in an outreach to different categories of people. Mission, it was said, has to do with "not-yetChristians", whereas evangelism tries to win back "no-more-Christians". The theological reason for the distinction was the presence or absence of (previous) covenant relations. Nowadays it is preferred to differentiate rather on the basis of an understanding of the essence of the two activities. Mission is understood as the broader activity of the church's involvement with the world, while evangelism is seen as the explicitly evangelising dimension of mission. This new understanding influences the traditional structuring of the church's work ad extra. This is illustrated in the case of the Dutch Reformed (Ned Geref) Church. Some relevant observations are made about the restructuring.

\section{AANLEIDING}

$\mathrm{Ek}$ is nie die eerste wat aan hierdie saak aandag gee nie. Onder andere het A C Barnard op die 1981 Predikantekonferensie van die Fakulteit Teologie van die Universiteit van Pretoria hierdie saak uitgebreid behandel ${ }^{2}$. Daarby het verskeie studiestukke voor sinodes van die Ned Geref Kerk gedien. Al hierdie werk was egter wesenlik rasionaliserings van 'n destyds bestaande praktyk in die Ned Geref Kerk $^{3}$.

In 1990 het die Algemene Sinode, na vooraf studie, besluit om die twee bestaande kommissies, naamlik vir Sending en vir Ampsbediening en Evangelisasie bymekaar te voeg 4 . Die nuwe kommissie is genoem die Kommissie vir Sending en Evangelisasie 5 . Die twee vorige kommissies se sake moes toe noodwendig met mekaar geïntegreer word. Daar is egter spoedig ontdek dat ook die grense met ander kommissies (by name Gemeentebediening en Diens van Barmhartigheid) nie meer so duidelik was nie. Dit is dus glad nie so seker dat die rasionaliseringsproses tussen die kommissies reeds 'n eindpunt bereik het nie. 
In die lig hiervan wil ek weer 'n keer kyk na die redes vir die integrasie, om sodoende meer duidelikheid te kry oor die verhouding tussen sending en evangelisasie. Ek wil egter ook moontlike verdere stappe onder oorweging neem.

\section{WAAROM DIE TWEE INTEGREER?}

\section{Redes vir die vroeëre skeiding}

Daar kan 'n saak uitgemaak word vir die onderskeiding tussen sending en evangelisasie. Die probleem is egter dat die twee aksies tradisioneel in die Ned Geref Kerk geskei is. Die oorspronklike onderskeiding het berus op ' $n$ teologiese argument, wat veral in die Nederlandse Gereformeerde kringe gebruik is ${ }^{6}$, en wat daarop neerkom dat sending en evangelisasie op verskillende objekte gerig is.

Volgens hierdie verbondsteologie is 'n duidelike grens tussen geloof en ongeloof veronderstel. Verbondskinders (gemeentelede) wat afgedwaal of teruggesak het, maak prinsipieel 'n ander kategorie uit as daardie mense wat nog nooit deur die doop ingelyf is in 'n gemeente nie. Sending het te doen met daardie mense buite die verbond, terwyl evangelisasie die terugroep van afgedwaaldes beoog. Sending werk dus na buite (ekstensiewe opbou), evangelisasie na binne (intensiewe opbou) ${ }^{7}$. 'n Algemene, maar onpresiese uitdrukking van die verskil tussen die twee aksies was: sending het met "nog-nie-christene" te doen, en evangelisasie met "nie-meer-christene"8.

Volgens die Ned Geref Kerk se Algemene Sinode van 1982 se formulering was evangelisasie die aktiwiteit om "diegene wat vervreemd is van Christus, sy Woord en sy Kerk en wat om die rede buite kerkverband geraak het... tot bekering te lei en weer in te lyf in die gemeente van Christus". Sendingwerk, aan die ander kant, lei tot die totstandkoming van (afsonderlike) jong kerke9. Sending is nie 'n "inbring huis toe" (soos evangelisasie) nie, maar die daarstelling van 'n nuwe tuiste.

Dat hierdie onderskeiding (om van skeiding nie eers te praat nie) heelwat probleme ingehou het, is deur almal erken ${ }^{10}$. Die grense tussen die twee kategorieë vervaag toenemend. Die mense buite die kerk verkeer deesdae iewers op 'n ongebroke kontinuum wat strek van pre- tot post-christendom. Deels is dit die gevolg van die volkskerke, waar die grense nie baie skerp getrek word nie en die doopplegtigheid gesekulariseer is tot 'n naamgewingsfunksie11. In so 'n situasie kom dit neer op 'n oorspanning van die verbondsteologie om nog op die wesenlike verskil tussen gedooptes en ongedooptes aan te dring.

Die weg uit hierdie dilemma is deur beide Barnard en De Klerk gesoek in kerkvernuwing, die herontdekking van die tug, ja, wat hulle genoem het "ampsbediening" of "verbondsherstel"12. Dit is dus die verleentheid met die onderskeiding 
tussen die objekte van sending en evangelisasie wat die Ned Geref Kerk daartoe gebring het om evangelisasie met "ampsbediening" in een kommissie te kombineer ${ }^{13}$.

Redes vir die integrasie van 1990

1 Soos hierbo aangedui, het die tradisionele (onder)skeiding onhoudbaar geword. Afgesien van enige prinsipiële probleme is die saak in Suid-Afrika verder verswaar deur die teenwoordigheid van kultuur (lees: rasse-) verskille.

Selfs ongelowige Westerse (blanke) mense moes, vanweë hulle agtergrond, in die praktyk as afgedwaalde christene beskou word - iewers in elke blanke se verlede lê tog 'n doop! Prinsipieel gesproke kon daar dus nie van sending onder blankes sprake wees nie, maar slegs van evangelisasie. Hierdie mense was egter moeilik uitkenbaar, en daarom het die werk van die kommissie vir evangelisasie verskraal totdat daar eindelik slegs klem gelê is op ampsbediening. Evangelisasie het tog oor die "eie mense" gegaan, en hulle was kerkmense. Hulle moes deur die normale bediening bereik word. Die uitreik na nie-christen blankes soos die Jode, en die bediening van die Portugese en anderstaliges, het ook by hierdie kommissie tereg gekom, en natururlik ook die "sending" in Portugal.

Andersyds is aanvaar dat alle ander volkere (die "nie-blankes" dus) nie hierdie "christelike" agtergrond deel nie, en daarom deur middel van die sending bereik moes word ${ }^{14}$. Daarom het 'n sendingkommissie in die praktyk die departement van nie-blanke sake van die Ned Geref Kerk geword. Die verkondiging van die evangelie aan die nie-blankes, en die verhoudings met en ondersteuning van die "dogterkerke", het die taak van die sendingkommissies geword (Die jongkerke het tereg beswaar gemaak daarteen dat die gesprek met hulle deur die sendingkommissies gevoer is... hulle was mos nie "heidene" nie!); leraars wat in die jong kerke gedien het, is beskou as sendelinge; en subsidies van hierdie Kerke se werk is as sendingbydraes beskou.

Die sending is dus kop en pootjies ingetrek in die kleurpolitiek. Sendingkommissies het aktief meegewerk aan die ontwerp en deurvoering van die, vir swartmense onaanvaarbare, beleid van afsonderlikheid. Dit het (soos te verwagte) ook ernstige spanning tussen die Ned Geref Kerk en die ander lede van die familie van Ned Geref Kerke laat ontstaan. Die sendingaksie van die Ned Geref Kerk het in die ongelukkige situasie beland dat dit weens politieke persepsies by die blankes onpopulêr geword het, maar terselfdertyd by die nie-blankes verwerping beleef het weens die paternalistiese aard en houding van die sendingbeleid. Dit alles was die gevolg van 'n konnotasie van kleur wat aan die sending gekleef het. 
Die onderskeiding tussen sending en evangelisasie wat op grond van die onderskeie objekte gemaak is, kon dus nie meer deurgaan nie. Trouens, die gebruik om hoegenaamd van "objekte" te praat, so word deesdae gevoel, verraai alreeds die selfversekerde en arrogante houding inherent aan die tradisionele sendingbenadering ${ }^{15}$. Dit weerspieël 'n houding dat die mense na wie toe ons met die evangelie gaan alleen maar "objekte" is. Van hulle is niks te leer nie. Daar is nie werklik respek nie, want dit is alleen maar 'n oorwinning wat ter sprake is. Ons "het dit", hulle nie, en ons moet "dit" alleen maar aflewer en die "objekte" oorreed om dit te aanvaar. Ons moet besef dat ons na ons medemense gaan, mense vir wie Christus gesterf het. Ons gaan in nederigheid, om hulle uit te nooi; ons probeer begryp waar hulle is en wat dit vir hulle kos om ons boodskap te aanvaar. Ons moet optree in die besef dat God mense voorberei vir die evangelie, en dat ons met wysheid by God se werk moet aansluit.

2 Veral onder leiding van $\mathrm{D} J$ Bosch is die hele gedagte om die onderskeiding te fundeer op die onderskeie objekte afgewys ten gunste van 'n groter klem op die aard van die twee aksies ${ }^{16}$. Bosch meen dat die aard van evangelisasie ${ }^{17}$ saamgevat kan word as in essensie 'n aankondiging (proklamasie), 'n uitnodiging, en 'n oproep18. "Prediking" is 'n woord wat te skraal is om die hele saak aan te dui. Ware evangelisasie is om die evangelie an te bied, om dit te "embody" (uit te leef). "Evangelism is invitation, not coaxing, much less threat"19, maar elkeen moet die geleentheid kry om daarop te reageer. Evangelisasie is 'n "oproep tot sending" 20 , nie slegs ' $n$ aanbod van verlossing nie, maar ook 'n roeping tot oorgawe en diens.

Bosch se kortste samevatting van wat sending is, is sy meermaal gebruikte formule: "Mission is the total task which God has set the Church for the salvation of the world"21. Hierdie kort formule staan egter altyd ingebed in meer uitgebreide "sending is" of "sending beteken" uitsprake, soos die volgende22:

* Mission has to do with the crossing of frontiers... It is the task of the Church in movement, the Church that lives for others...

${ }^{*}$ Mission is the symbol of the Church moving towards the world.

*Mission takes place where the Church, in her total involvement with the world and the comprehensiveness of her message, bears her testimony in word and deed in the form of a servant, with reference to unbelief, exploitation, discrimination and violence, but also with reference to salvation, healing, liberation, reconciliation and righteousness. 
Die omvang van sending is omvattend, so wydstrekkend as die heil self. Die koninkryk van God in al sy volheid is die fokus van die sending. Sending is die uitdrukking van God se liefde vir en kommer oor die ganse wêreld in al sy dimensies. Daarom is sending altyd kontekstueel, ingebed in die nood van die besondere plek en tyd 23 .

Sending is dus ' $n$ breër begrip as evangelisasie, al kan evangelisasie wel beskou word as die kern (die hart) van die sending. Sending omsluit ook ander betrokkenhede en geroepenhede van die kerk in die wêreld, maar nooit mag daar 'n wig tussen die verskillende dimensies van sending ingedryf word nie. Evangelisering, sosiale diens, gemeenskapstigting is almal deel van dieselfde evangeliese uitwaartse beweging van die kerk tot die wêreld en tot eer van God.

$3 \quad$ As hierdie wyse van onderskeiding aanvaar word, en dit is waar die Ned Geref Kerk homself amptelik bevind ${ }^{24}$, dan is daar geen moontlikheid meer om die ou onderskeiding en skeiding te handhaaf nie. Die Ned Geref Kerk kon in werklikheid nie anders as om die twee kommissies saam te smelt nie. Sending en evangelisasie hoort bymekaar.

In die lig hiervan is dit onbegryplik dat hierdie skeiding tot 'n groot mate steeds in die beoefening van die teologie, en in die strukturering van teologiese opleiding, voortgesit word 25 . Evangelisasie word skynbaar steeds beskou as die "interne" aktiwiteit van die gemeente in die bereiking van die afgedwaaldes, en daarom tot die studieveld van die Praktiese Teologie 26 (Evangelistiek) gereken, terwyl die Sendingwetenskap verwag word om met die bereiking van onbereikte mense en die praktyk van "kruiskulturele sending" te handel... alhoewel hy tog ook aandag moet gee aan die opbou van 'n gemeente tot missionêre betrokkenheid. Basies behoort die problematiek van die kerk in Derde Wêreld gemeenskappe by Sendingwetenskap, nie by Praktiese Teologie nie ${ }^{27}$. Hierdie werksverdelings is klaarblyklik ad hoc, maar ongelukkig reflekteer dit veel van die onaanvaarbare uitgangspunte van vroeër. Dit is beslis belangrik dat die nuwe sieninge ook hierin sal deurwerk.

\section{WAS HIERDIE HERSTRUKTURERING VOLDOENDE?}

Die vraag kan nou gevra word of hierdie samevoeging (met die afstaan van "ampsbediening" aan die kommissie vir Gemeentebediening) voldoende is. Waarom word nog verdere onderhandelinge gevoer ${ }^{28}$ ? 
Wat behels die werksaamhede van die nuwe kommissie?

Soos hierbo aangedui, word die sendingtaak nou in omvattende terme gesien. Ons het begin praat van 'n driedimensionele begrip van sending29. Op voetspoor van Hoekendijk en ander is die omvattende roeping van die kerk in die wêreld (sy marturia, getuienis) verstaan as bestaande uit ten minste (a) die evangeliseringswerk (euangelizomai of kerygma), (b) die liefdesdiens (diakonia), en (c) die opbou van die gemeenskap (koinonia) ${ }^{30}$.

*Onder die evangeliserende dimensie (waarmee ek so min of meer aandui die tradisionele begrip evangelisasie) word verstaan die kommunikasie van die evangelie aan mense, in woord en daad ${ }^{31}$, met die bedoeling om hulle tot geloof in Christus op te roep, sodat hulle daartoe sal kom om Hom as Verlosser en Here te bely en by ' $n$ kerk gevoeg te word.

* Die missionêre diakonaat (die diens van barmhartigheid wat na buite kyk, nie net "ons eie mense" raaksien nie) steek, op die voetspoor van Jesus Christus, 'n liefdevolle hand uit na noodlydendes. Terwyl die onmiddellike behoeftes van mense deur aksies van versorging en noodhulp aangespreek moet word, kan dit nie daarby bly nie. Dit sou 'n verskraalde diens wees as die oorsake van die leed nie ook gepak word nie. Daarom lei die diakonale diens ook noodwendig tot die diens van geregtigheid en, indien dit nodig sou wees, 'n politieke diakonaat ${ }^{32}$.

*As die derde dimensie van die sendingtaak hou die begrip koinonia meer in as net maar die saamwees van christene. Dit vereis die aktiewe bevordering van eenheid, en die opbou van die christengemeenskap in liefde, geloof en waarheid. Dit is in wese gemeenskapstigtend.

Hierdie omvattende sendingtaak is reeds met ' $n$ aantal eenvoudige beelde geillustreer.

*Wanneer 'n wit ligstraal deur 'n prisma geprojekteer word, vertoon dit al die kleure van die spektrum. Netso, wanneer die evangelie in die wêreld uitgedra word, val hierdie enkele betrokkenheid uit in 'n aantal aksies wat, hoewel verskillend in hulle aard, tog grondig met mekaar verband hou. Elke aksie behoort by die geheel, en die geheel is anders as bloot die som van die dele. Dieselfde het gebeur toe Jesus (die helder wit lig) sy goddelike sending in die prisma van die menslike werklikheid kom uitleef het.

*'n Skêr het twee lemme nodig om te kan funksioneer, maar ook die beste lemme is nutteloos as hulle nie aan mekaar geheg word by 'n punt nie. By die omvattende sending is hierdie skarnier die koinonia, waarsonder dit onmoontlik is dat die woorddiens (kerygma) en die daaddiens (diakonia) 'n indruk kan maak. Terwyl Jesus Homself in woord en daad uitgegiet het vir die armes en noodlyden- 
des, het Hy dit steeds nodig gevind om Homself terug te trek in die gemeenskap van sy engere dissipelkring, en in sy gemeenskap met die Vader. Terwyl Hy verkondig en genees het, het Hy altyddeur gebou aan gemeenskap.

*Bosch het ook met instemming die Church Missionary Society (CMS) se model gebruik ${ }^{33}$. Daarvolgens is sending soos 'n sirkel rondom drie onderling oorvleuelende kleiner sirkels, wat onderskeidelik voorstel: die deelname aan die uitdra van die evangelie; die deelname aan die stryd om 'n samelewing wat voldoen aan die eise van die evangelie; en die deelname aan die vernuwing van die kerk ${ }^{34}$. Daar moet net onthou word, sê Bosch, dat hierdie beeld nie staties verstaan moet word nie. Hierdie buitenste sirkel (die omvattende sendingtaak) du na buite, die wêreld in. Sending steur hom nie aan die grense wat mense verdeel nie. Trouens, sending is wesenlik die oorsteek van grense.

Inderdaad het die Ned Geref Kerk se (nuwe) kommissie vir sending en evangelisasie met 'n omvattende agenda gesit.

Benewens die aspekte van die woordbediening (evangelisering van onbereikte mense, die bediening van die arbeidswêreld, die geruislose uittog van lidmate, ensovoorts) wat aandag bly geniet, dring allerlei ernstige diakonale sake op sosiomaatskaplike gebied hulle aan die kommissie op (betrokkenheid by woningnood, plakkery, armoede, werkloosheid, plattelandse ontwikkeling, ensovoorts). Hierdie aspekte van diens ten opsigte van die nood in die wêreld is geheel en al deel van die kerk se sendingroeping.

Daarby is die verhoudinge met die eertydse dogterkerke sentraal in die uitvoering van die hele taak, nie alleen omdat daar personeel beskikbaar gestel word en bepaalde werksaamhede gesubsidieer word nie, maar omdat daar ' $n$ beleid van gesamentlike sendingwerk bestaan - ekumeniese verhoudinge dus.

Netso is aspekte van die gemeentebediening, naamlik die opbou van die gemeente tot diensbereidheid en diensgeskiktheid, grondliggend aan die kerk se sending.

Hoe kan al hierdie bykomende elemente ook bevredigend in die agenda van die kommissie vir sending en evangelisasie aandag geniet? Sending is voorwaar die oorsteek van grense, maar wat nou gemaak met die grense van kommissiewerksaamhede?

\section{Strukturering}

Die eerste beweging van 'n herstrukturering in die Ned Geref Kerk het wel plaasgevind: sending en evangelisasie, wat kennelik bymekaar hoort, is saamgevoeg. Maar wanneer "sending" gesê word, word al die dimensies van die beweging van die 
kerk na buite bedoel. Daar is dus elemente hiervan wat nog nie in hierdie kommissie verteenwoordig word nie. Hoe kan dit gestruktureer word? ${ }^{35}$

Ekself voel dat in die kerk se werk uiteindelik maar slegs onderskei behoort te word tussen die twee gerigthede: na binne (ad intra) en na buite ( $a d$ extra). Sending/evangelisasie is duidelik dan die kern van die kerk se werk na buite (al sluit dit tans nie alles in wat na buite gerig behoort te wees nie). Die werk na binne en na buite kan of mag nie geskei word nie, want dit is op mekaar aangewese, en vorm die twee kante van 'n muntstuk. Terselfdertyd is die omvattende bediening na binne en dié na buite ook aan mekaar verbonde omdat hulle op dieselfde manier multi-dimensioneel is, omdat dit dieselfde omvattende evangelie is wat bedien word.

Agter enige onderskeiding lê die gevaar van skeiding natuurlik op die loer. Dalk sou hierdie gevaar op die lang duur ten beste vermy kan word as daar weggedoen word met vaste kommissies, wat geneig is om grense te bestendig, en taakgroepe aan te wys om bepaalde take uit te voer en sover moontlik af te handel. Op die plaaslike gemeentevlak is dit duidelik 'n maklike manier van doen: alle werksaamhede word deur die kerkraad gekoördineer, wat die eenheid daarvan demonstreer, maar dit word uitgevoer deur geskikte persone. Op sinodale vlak is daar dalk ander faktore wat in ag geneem moet word. Nogtans verdien dit myns insiens oorweging om so min as moontlik kommissies te hè - mits die lidmate betrokke kan raak in die taakgroepe.

\section{Terminologie}

Die nuwe saamgevoegde kommissie se naam het heelwat bespreking uitgelok. Uiteindelik is die twee historiese name maar saamgevoeg in Sending en Evangelisasie $^{36}$. Die probleem is nou dat, as die uiteensetting hierbo aanvaar word, ons 'n samevoeging het van twee terme wat nie op dieselfde vlak is nie. Evangelisasie is een aspek van sending. In werklikheid moes òf slegs die naam sending in sy omvattende sin behou word, of die ander elemente van sending moes saam met evangelisasie in 'n (beskrywende) naam gebruik word.

Daarom dink ek sou die naam, wat deur Wes-Kaapland voorgestaan, en reeds in die NG Sendingkerk in gebruik was (en later deur die gesamentlike kommissie in die Wes-Kaap oorgeneem sou word), naamlik Getuienisaksie, 'n beter besluit gewees het. In hierdie naam is die essensie van die taak waartoe die kerk in die wêreld geroep is, uitgedruk: "julle sal my getuies wees..." (Hd 1:8). Dit omsluit wat ons met die omvattende sending bedoel, al sou die term veral aan die begin nog verduideliking verg 37 . Trouens, dit sou as naam kon bly dien selfs al word die samestelling verder verbreed om ook elemente van diakonale dienste en 
gemeentebediening in te sluit, want die bestaanswyse van die kerk in die wêreld is dié van getuienis.

\section{KERK IN DIE NUWE WêRELD}

In hierdie oefening van na te dink oor die strukturering en benaming van die kerk se omvattende taak in die wêreld, is dit belangrik om nie net agtertoe te kyk en die historiese kontinuîteit te probeer behou nie, maar ook vorentoe te kyk na die toekoms, en veral ook te kyk na die veranderde konteks.

\section{Nuwe konteks}

Ek lig slegs twee elemente van die veranderde konteks uit: die kerk het verander, en die omstandighede van die kerk het verander.

Die Ned Geref Kerk is op die moeisame pad van hereniging met die familiekerke. In die geloofsoog verskyn die verenigde 38 kerk reeds voor in die pad. Vir etlike jare al geld die beleid van gesamentlike sendingwerk, want die Ned Geref Kerk het tot die besef gekom dat hy nie buite sy mure geisoleerd van sy suster/dogterkerke kan optree nie. Tog het daar van hierdie gesamentlikheid nog min tereg gekom, hoofsaaklik omdat die besluitneming nog nie gesamentlik kon plaasvind nie. Die verhoudingskrisis is deeglik op die terrein van gesamentlike aksie gereflekteer. Dit is duidelik dat die Ned Geref Kerk ook moet ophou om eensydig oor sy taak in die wêreld na te dink en besluite te neem.

Dit lyk vir my asof die herstrukturering van die "sending"kommissies verder moet gaan as ' $n$ blote interne (Ned Geref Kerk) oefening. Hierdie kommissies sal die gesamentlikheid moet vertoon en oefen. In die Wes-Kaapland het hierdie proses al ver gevorder, en by die algemene sinodale kommissie word ernstig daaraan aandag gegee. Dit lyk vir my noodsaaklik met die oog op die toekoms. In lyn met wat hierbo beredeneer is, is hierdie herstrukturering in sigself reeds deel van die koinoniaal-missionêre taak van die kerk. Maklik sal dic nie wees nie, maar dit is deel van die getuienis wat in die wêreld te lewer is.

Die kerk self het verander, maar mede as gevolg van sy veranderde omstandighede. Die sendingtaak in die omgewing van die kerk sien daar kwalitatief anders uit as toe die tradisionele strukturering onderneem is. Intussen is SuidAfrika geëvangeliseer, "bereik"39. Die her-evangelisering, die geloofwaardig maak van die kerk en sy boodskap, vra tans prioriteitsaandag. Die woord "getuienis", wat so duidelik insluit die bestaanswyse van die kerk, druk myns insiens die rol van die kerk in die hedendaagse Suid-Afrika beter uit as die ou aggressiewe "evangelisasie". Dan moet besef word dat die geloofwaardigheid van die kerk juis afhang van die 
sigbare tekens van liefde en eenheid wat deel van die kerk se beeld moet wees ${ }^{40}$.

\section{Nuwe styl}

Daarmee is ' $n$ aanduiding van die nuwe styl van die kerk se getuienis in die wèreld reeds gegee. Dit moet deur nederige en liefdevolle diensbereidheid gekenmerk word. Die kerk - en veral die Ned Geref Kerk - het nie meer in 'n magsposisie in die samelewing nie. Nie die selfversekerde effektiwiteit en die inset van groot bedrae geld moet die styl van sendingwerk kenmerk nie, maar 'n opofferende liefde en evangeliese openheid. Ook vanuit hierdie hoek gesien, is dit noodsaaklik dat die diakonale en koinoniale dimensies struktureel aan die evangeliserende werk verbind moet word.

NOTAS:

1 Ek wil graag hierdie artikel opdra aan ons oorlede vriend en leermeester, David Bosch. Hy sou vanjaar op 13 Desember aftree-ouderdom bereik het, maar is reeds vroeër opgeroep. Hierdie tema was eintlik die sentrale saak van sy teologiese arbeid in die tagtigerjare. Vergelyk J J Kritzinger, "Mission and evangelism: a critical appraisal of David Bosch's views", Missionalia 18 (1990), 140-155.

2 A C Barnard, "Die verhouding tussen evangelisasie en sending", Predikantekonferensie 1981, Ongepubliseerde referaat, 40-59.

3 Ek spits hierdie artikel toe op die praktyk en filosofie in die Ned Geref Kerk, maar dit raak sake aan wat vir ander Kerke ook van belang is.

4 Die Ampsbediening deel van die kommissie het die kern geword van 'n nuwe kommissie vir Gemeentebediening. Ons sal later weer hierop terugkom.

5 Hierdie benaming is in 'n stemming verkies bo die Wes-Kaapland voorgestelde Getuienisaksie, die naam wat reeds deur die NG Sendingkerk gebruik is, en wat in die volgende jare ook deur die gesamentlike kommissie in die Wes-Kaap gebruik sou word.

6 Ek spits hierdie artikel toe op die praktyk en filosofie in die Ned Geref Kerk, maar dit raak sake aan wat vir ander Kerke ook van belang is.

7 Vergelyk hiervoor ook J J de Klerk, Evangelistiek, Pretoria 1979, 17.

8 Dit is inderdaad 'n onbevredigende wyse van formulering (soos Barnard, $a w$, 47 aandui). Wat sou dan die betekenis van christenskap wees as "christene" nie-meer- of nog-nie-christene sou kon wees? Buitendien, volgens die verbondsargument is laasgenoemdes nog steeds christene, of nie? 
9 Volgens die algemeen aanvaarde sendingbeleid van die Ned Geref Kerk was afsonderlike kerkvorming 'n belangrike doel van sending. Die Ned Geref Kerk was trots daarop dat dit inderdaad in verskillende lande gebeur het, as vrug op sy sendingwerk.

So Barnard, $a w, 45$ en de Klerk, $a w, 19$.

11 Dit is natuurlik veral in die "christelike" Weste die geval. Daar is die volkskultuur diepgaande deur die kerkgeskiedenis help vorm, maar is die wesenlike van kerkwees vir die groot meerderheid nie meer ter sake nie.

12 Kyk Barnard, $a w, 49$ en de Klerk, $a w, 18$.

13 Benewens die "binne" van die ware gelowiges, en die "buite" van die heidene, het daar volgens Barnard in die praktyk 'n grys area tussen die kerk en die wêreld ingeskuif. Die ideaal en werklikheid kom nie ooreen nie. Barnard het hierdie drie terreine by wyse van konsentriese sirkels voorgestel: die middelste sou die terrein van die ampsbediening wees, dit is die gemeente; dan volg die eerste (grys) kring, die terrein vir evangelisasie; en daaromheen die kring van die sending, wat strek tot die uithoeke van die wêreld (Barnard, $a w, 50-51)$.

14 "Nie-blankes" is eintlik as nie-christene beskou, ten spyte van die feit dat die oorweldigende meerderheid christene in die land reeds "mense van kleur" was. Reeds vir 'n halfeeu of langer behoort die groot meerderheid swartmense aan christelike Kerke. Trouens, die 1980 sensus het aangedui dat die Tswanas (byvoorbeeld) reeds dieselfde persentasie kerklike aanhang had as die blankes (meer as $91 \%$ ). Uit J J Kritzinger, Die godsdiens-mosaiek van Suid-Afrika, Pretoria 1986, 16 en 18.

15 Dit is veral Theo Sundermeier wat hier 'n nuwe weg opgegaan het. Hy praat van "Konvivenz", begrypende kommunikasie, die aanvul van mekaar in die proses van getuienis. Een aanhaling kan aandui wat hy bedoel: "The prophetic word does not exist without those for whose ears it is intended. The other is therefore by definition not merely the object of the message, but also its subject. Like faith, therefore, testimony receives life from the act of listening, listening to the word of God and to the other, the stranger, in whose features the face of God becomes visible" ("Missiology yesterday and tomorrow", Missionalia 18 (1990), 266).

16 Vergelyk my bogenoemde artikel oor die gedagtes van Bosch. Barnard ( $a w$, 48 ) is reg as hy sê dat 'n ontleding van die verskillende Nuwe-Testamentiese woorde nie veel help om 'n onderskeiding daar te stel nie, maar die deeglike artikel van Bosch, "Mission and evangelism: clarifying the concepts", Zeitschrift für Missionswissenschaft und Religionswissenschaft 68 (1984), 161191 , skep tog 'n goeie basis om op voort te bou.

17 Ons sou in hierdie verband eerder wou praat van evangelisering as 
evangelisasie. Laasgenoemde het die konnotasie van 'n bepaalde aksie, 'n organisasie verkry, terwyl eersgenoemde meer die aard van die aktiwiteit aandui.

18 Kyk Kritzinger, $a w, 1990,151-153$.

19 Bosch, $a w, 1984,171$.

20 Bosch, $a w, 173$.

$21 \quad$ Kyk Kritzinger, $a w, 1990,147$.

22 J Bosch, Witness to the world, Atlanta 1980, 17-18.

23 Vergelyk hiervoor Kritzinger, $a w, 147-149$.

24 In die Sendingreglement en Artikel 53 van die Kerkorde word die sendingbegrip ván die Ned Geref Kerk pragtig uitgespel om presies dieselfde te sê as wat hier uiteengesit is. Dit beteken nie dat hierdie breër sendingbegrip veel verder in die Kerk deurgedring het as die papier waarop dit geskrywe staan nie. Waarskynlik is dit die enger begrip - waar sending, soos evangelisasie, slegs te doen het met die mondelinge verkondiging van die evangelie, en die redding van sondaars - wat by die meeste predikante en lidmate van die kerk funksioneer.

25 Ek is daarvan bewus dat die meeste opleidingsplekke hieraan werk. Hierdie moet dus nie as 'n algemeen geldige oordeel gesien word nie, maar eerder as 'n oproep om meer erns met die noodsaaklike herstrukturering te maak.

26 Hierdie vakgebied staan natuurlik onder verskeie name bekend, wat telkens 'n ander beklemtoning reflekteer.

27 Uiteindelik lyk die verdeling tussen Praktiese Teologie en Missiologie baie soos die ou kulturele of kleurverdeling tussen evangelisasie en sending: die een is georienteer op Westerse mense, die ander op "mense van kleur"! Sendingwetenskap is die departement Afrikasake van die teologie.

28 Dit is bekend dat die Sending- en Evangelisasiekommissie met die kommissies vir Gemeentebediening en Diens van Barmhartigheid hulle onderskeie raakpunte bespreek.

29 Vergelyk hiervoor my Die onvoltooide sendingtaak in Suid-Afrika, Pretoria 1988, 34-36.

30 'n Vierde dimensie wat dikwels (grootliks tereg) bygevoeg word, is leitourgia, die aanbiddingselement. Trouens, daar kan nog ander belangrike elemente bygevoeg word (soos J J du Preez se "Tiendimensionele sending", ISWENKommunikasie 7 (1985), 1-24), maar onder die drie dimensies wat hier genoem word, kan al die ander wel tuisgebring word. 
31 Dit is hier waar die tradisionele evangelisasie meestal tekort geskiet het. Evangelisasie is beperk tot woorddiens. Waar sending darem nog omvattend na mense gekyk het, was evangelisasie bloot ingestel op die evangelieboodskap, en hoofsaaklik binne die mure van die kerk.

32 Politiek is die ordening van die gemeenskap. Die deelname aan die soeke na 'n samelewing warin mense nie tekort gedoen word nie, kan politieke diakonaat genoem word.

33 Hy het dit geillustreer in die boekie geredigeer deur Phil Robinson en Johan Botha, Wat is sending?' 'n Werkswinkel vir die familie van NG Kerke, Belhar 1986, 115-121.

34 Mike McCoy het onlangs (in "Equipping the people of God for Christian witness: an Anglican account", International Review of Mission 328 (1994), 47) met 'n pragtige aanpassing hiervan gekom. Die drie "missional vocations", soos hy dit noem, wat gesamentlik die holistiese sending uitmaak, is "evangelism - proclaiming God's forgiveness"; "the service of the poor and needy - proclaiming God's compassion"; en "the search for justice, peace and the integrity of creation - proclaiming God's holiness".

35 Hier volg maar enkele opmerkings oor ingewikkelde histories gegroeide sake en is nie bedoel as finale voorstelle nie. Ek is bewus daarvan dat kommissies hieroor samesprekings voer en voorstelle formuleer.

36 Dit lyk asof die sinode nie verder wou gaan as om twee kommissies saam te voeg nie. Die prinsipiële samevoeging van twee werksaamhede is nie radikaal deurdink nie. Daarom is, ter wille van die bekendheid van die terme, met 'n samevoeging volstaan. Die alternatiewe naam Getuienisaksie sou wel 'n prinsipiële verskuiwing behels.

37 Die verduideliking is in ieder geval nodig, aangesien ook die ou begrippe sending en evangelisasie gebuk gaan onder baie misverstande.

38 Die NG Sendingkerk en die Ned Geref Kerk in Afrika het reeds in April 1994 verenig as die Verenigende Gereformeerde Kerk - die proses is aan die gang.

39 Ek praat hier van die Suid-Afrikaanse konteks. Die wêreldkonteks bring ook ander aspekte na vore, soos die werklike "onbereiktheid" van 'n groot deel van die bevolking. Tog meen ek dat die taak van die kerk ook wêreldwyd verander het.

40 Vergelyk die belangrike artikel van A B du Toit, "Die geloofwaardigheid van die kerk en sy boodskap - enkele Nuwe-Testamentiese perspektiewe", NGTT 22 (1981), 166-178. 